\title{
The Clann Carthaigh (continued)
}

\section{Author(s): S. T.}

Source: Kerry Archaeological Magazine, Vol. 3, No. 16 (Apr., 1916), pp. 271-292

Stable URL: http://www.jstor.org/stable/30059748

Accessed: 22-06-2016 22:15 UTC

Your use of the JSTOR archive indicates your acceptance of the Terms \& Conditions of Use, available at

http://about.jstor.org/terms

JSTOR is a not-for-profit service that helps scholars, researchers, and students discover, use, and build upon a wide range of content in a trusted digital archive. We use information technology and tools to increase productivity and facilitate new forms of scholarship. For more information about JSTOR, please contact support@jstor.org. 


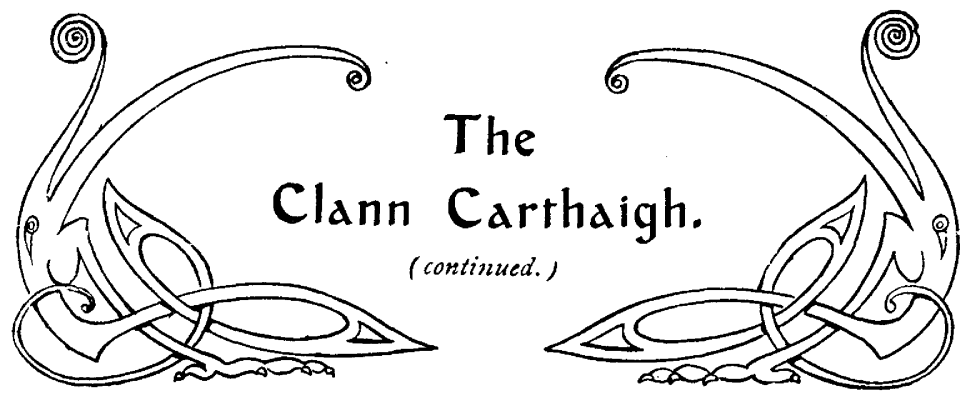

THE MACCARTHYS RABACH.

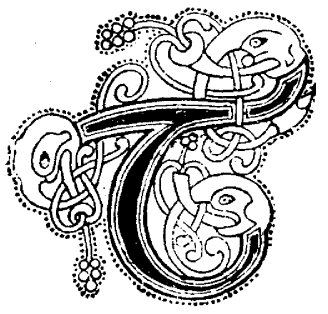

HE MacCarthys Rabach were a branch of the MacCarthys Reagh, Princes of Carbery. Donal Reagh, who married Johanna Fitzmaurice, had by her, besides other sons, one named Donogh of Iniskeen. He was the ancestor of the Slught Dermod of Iniskeen, and also of the MacCarthys Rabach, as shown by the following pedigree :-

Donogh of Iniskeen.

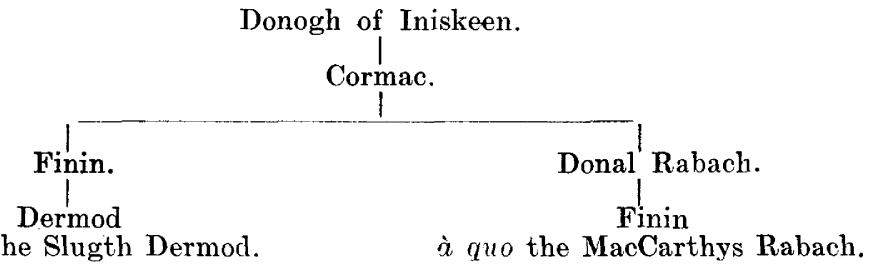

A notable member of the Rabach Sept was the Right Rev. Florence MacCarthy, Catholic Bishop of Antinoe in partibus infidelium and Coadjutor Bishop of Cork, who died more than a century ago. He was born at Macroom in 1761. His parents went to reside at Killarney, where dwelt Dr. Moylan, then Bishop of Kerry. Having soon attracted that prelate's affectionate interest, young Florence was, in 1777, appointed by him to a place in the Irish College at Rome, where he remained for eight years. Before he was twenty-five years of age he obtained his degree of Doctor in Divinity, and was held in high estimation. One of the Cardinals, then Papal Secretary of State, having determined to go on a tour 
through Italy and part of France, made choice of Dr. MacCarthy as the companion of his journey, and sent to the Irish College an invitation to that effect. But the youthful D.D. had already quitted Rome for his own country. He arrived in 1785, and became Curate to Dr. Moylan at Killarney. When the latter was promoted to the See of Cork he made Dr. MacCarthy his Vicar-General, and placed him over the parish of SS. Peter and Paul, whence some years later he was removed to the South Parish, the Catholic population of which then numbered more than 20,000 souls. In 1803 he was named Bishop of Antinoe and Coadjutor to Dr. Moylan, but he still continued to discharge his laborious duties in common with the Curates of his parish, his iron constitution enabling him to go through an immense amount of work, in the pulpit, the confessional, and among the poor. His death was worthy of his life. Passing one day through a part of the City, not in his own district, but in which fever was raging, he was asked to enter a house and see a patient who was on the point of death. A neighbour, knowing the virulence of the poor creature's disease, begged of the Bishop not to risk his life by going in. "I will go," he answered, "and save that soul!" He did all that could be done for the dying man, took the contagion, and after ten days' illness died, before he had reached his fiftieth year, on the 10th June, 1810.

A monument of great merit was erected to his memory in St. Finbar's, the Church of the South Parish, in which he had last ministered.

\section{THE CLAN TEIGE ROE.}

Of the many sorrows which darkened the reign of Dermod MacCarthy, King of Cork and Prince of Desmond, who died in 1185, not the least bitter was the rebellion of his eldest son, Cormac Liathanach. That this rebellion, and the imprisonment of his father, was looked upon by his Sept as a serious crime was evidenced by their disinheriting his posterity from succession to the throne of his ancestors. According to a pedigree preserved in the Lambeth Palace Library, Cormac Liathanach had a son Owen, and his son Tadhg Ruadh 


\section{PEDIGREE OF THE MAC CARTHYS As Compiled by Sir George Carew in 1602-Copied from Carew Paper}

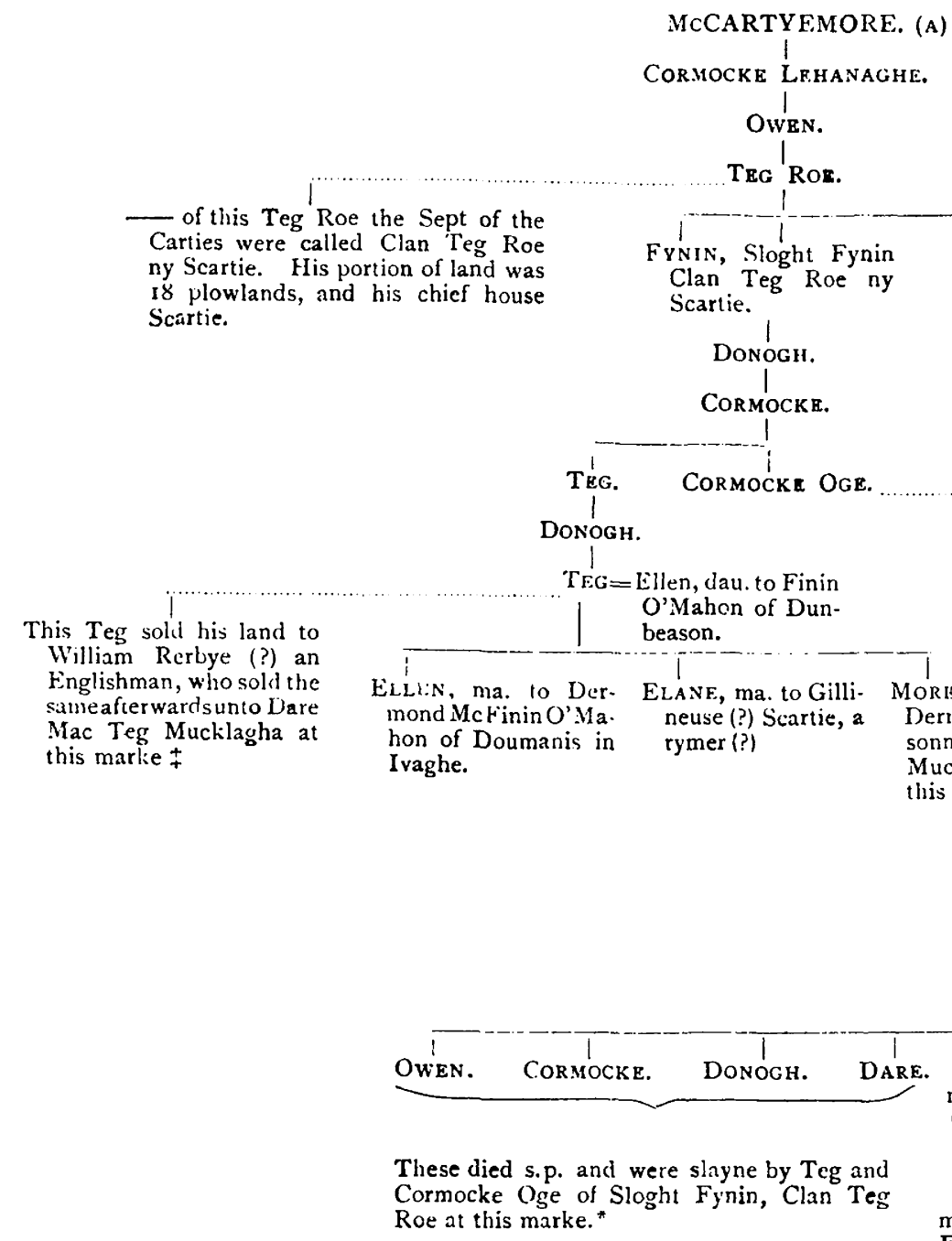




\section{¿ CARTHYS OF CLAN TEIGE ROE}

d from Carew Papers, Vol. 635, page 184 in Lambeth Palace Library.

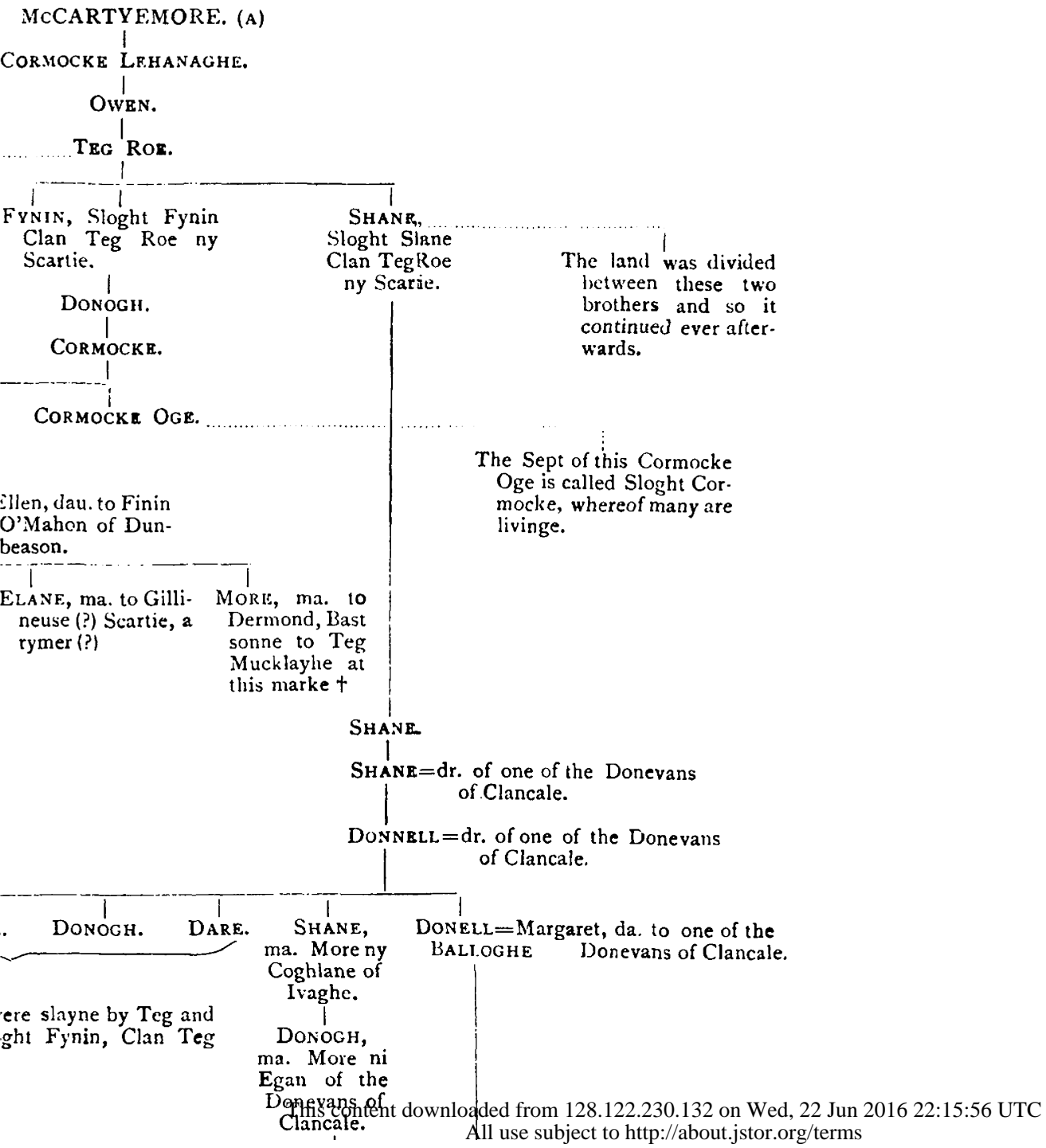

The Sept of this Cormocke Oge is called Sloght Cormocke, whereof many are livinge. 
Cormocke Oge of Sloght Fynin, Clan Teg

Roe at this marke.*

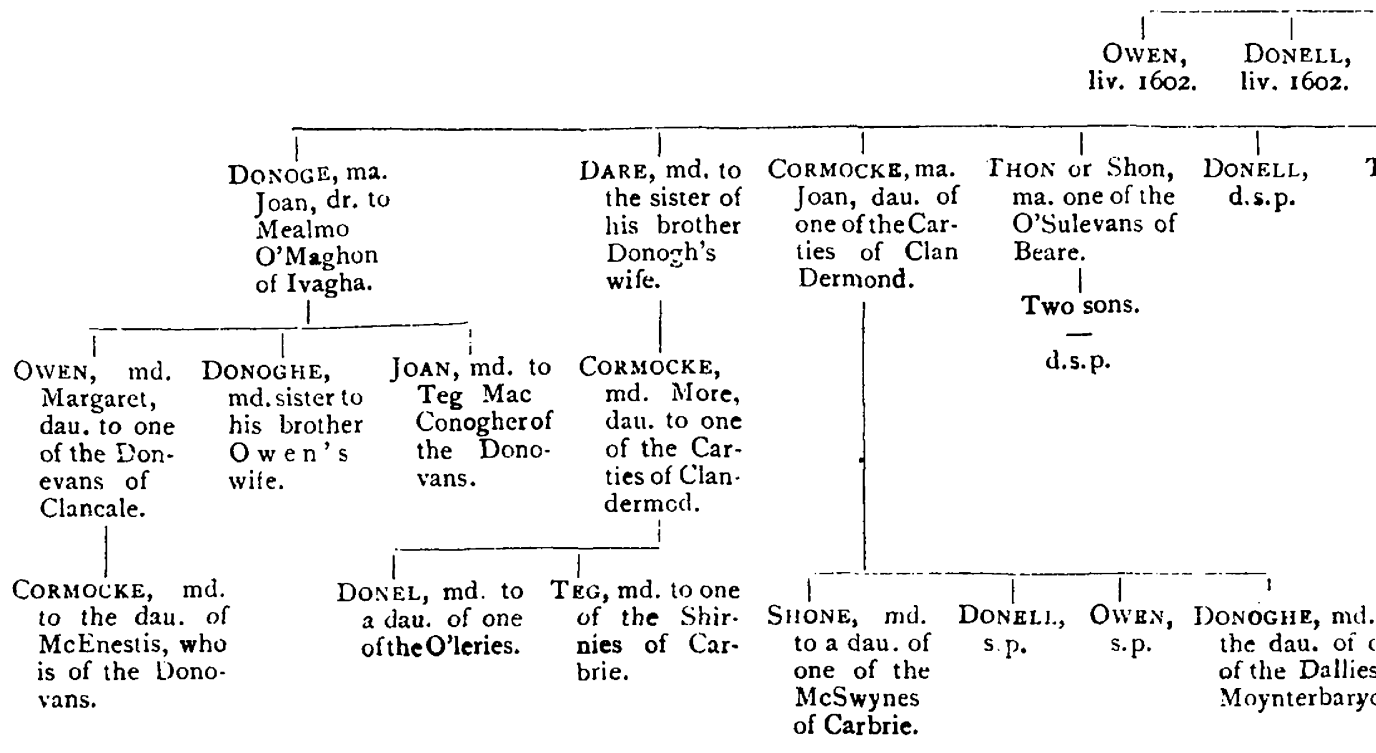

Dermond, $=$ More, dau. to Teg eldest son McDonoghe of a bastard. Sloght Fynin McTeg Roe ny Scartie at this marke t ante in this pedigree.
Dare. DoNeli. Teg. More. MargRev.

HONOR, md. to Willm Donell O'Boyhan of Ivaghe.

Cormick. TEg. Margaret. DONELL.

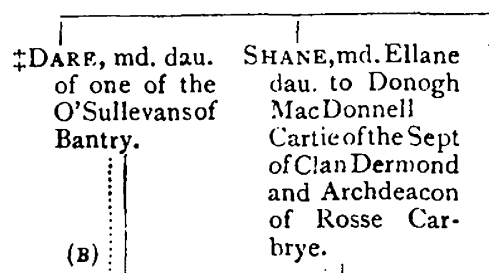

DONELL, md. Honor, dau. to Cormocke Mac Donell Cartie of the Sept of Clan Dermond and owner of Kilco.

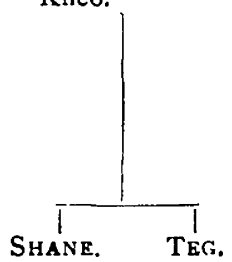


DONOGH,

ma. More ni

Egan of the

Donevans of

Clancale.

OWEN, DONELL, EI.I.ANE.

liv. 1602. liv. 1602 .

\begin{tabular}{|c|c|c|c|c|c|}
\hline 1 & & 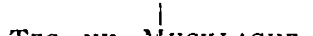 & 1 & & \\
\hline $\begin{array}{l}\text { Nor Shon, } \\
\text { a. one of the } \\
\text { Sulevans of } \\
\text { eare. }\end{array}$ & $\begin{array}{c}\text { DONELL, } \\
\text { d.s.p. }\end{array}$ & $\begin{array}{l}\text { TEG NY MUCK LAGIE, } \\
\text { liv. I602 and } 97 \text { years } \\
\text { old and in rebelliun, ma. } \\
\text { Margaret, dau, to Teg } \\
\text { MacDermond O'Dris. }\end{array}$ & $\begin{array}{l}\text { SHIt., md. to } \\
\text { Ommunye of } \\
\text { Kinel Muck- } \\
\text { laghe. }\end{array}$ & $\begin{array}{l}\text { Marg., md. Finin } \\
\text { MacTeg Mac- } \\
\text { Mealmo O'Ma- } \\
\text { hon of Ivagha. }\end{array}$ & $\begin{array}{l}\text { BatнRAMI, m } \\
\text { Desmond(?) C } \\
\text { Keghe O'Dri } \\
\text { coll. }\end{array}$ \\
\hline
\end{tabular}

wo sons.

d.s.p.

coll.

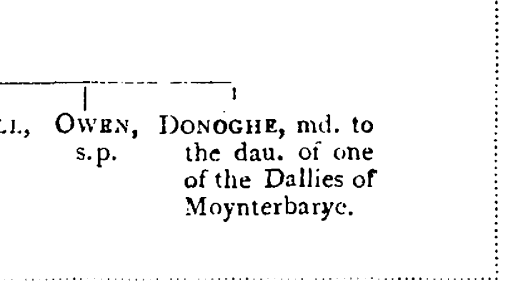

(B)

SHYLIE, mol. Donugh Oge (') Megan of Ivaghe.
Cnogher Mav - of the O'Megans in Ivaghe. to Domogh

O'Bryan of Ivaghe:

\section{1}

\begin{tabular}{|c|c|c|c|c|}
\hline DWEN. & $\mathrm{COr}$ & $\begin{array}{l}\text { HONOR, md. } \\
\text { to Domogh } \\
\text { O'Bryam of } \\
\text { Ivaghe:. }\end{array}$ & $\begin{array}{l}\text { JoANE, md. to } \\
\text { Cnogher Mac } \\
\text { O'Megans in } \\
\text { Ivaghe. }\end{array}$ & $\begin{array}{l}\text { SHYLIE, mol } \\
\text { Donugh Oge } \\
\text { O'Megan o } \\
\text { Ivaghe. }\end{array}$ \\
\hline
\end{tabular}

\begin{tabular}{|c|c|c|}
\hline & & \\
\hline $\begin{array}{l}\text { ILANE, md. } \\
\text { Hugh Murry } \\
\text { of Sept of } \\
\text { O'Driscoll } \\
\text { Oge. }\end{array}$ & $\begin{array}{l}\text { CathERINE. } \\
\text { md. Teg } \\
\text { McDonell } \\
\text { of the Sule- } \\
\text { vans of }\end{array}$ & $\begin{array}{l}\text { MaRGREAD, md. } \\
\text { Shane Oge Mac } \\
\text { Shane O'Mo- } \\
\text { roghe. }\end{array}$ \\
\hline
\end{tabular}

Beare.

(A) This was Dermod Mor-na Cille Baghain who was Prince of Desmond and King of Cork, I144-1185.

(B) The dotted lines denote illegitimate offspring. 
gave the name to clan of which we now treat. Its full name is the "Clann Tadhg Ruaidh-na-Scairte," so called from a place called Scart, situate in the Parish of Kilmocomogue and Barony of West Carbery in the Co. Cork. It is commonly written Clan Teige Roe, and to this spelling we shall adhere throughout the present paper. There was formerly a castle there, of which only the foundations remain.

As was usual in such cases, the disinherited party was granted a small territory in an outlying district. When exactly this grant was made, and what its original extent was, is not clearly known; but, at the time of the Survey of 1650 , its extent seems to have been limited to the parishes of Kilmocomogue and Durrus, and a small part of Caheragh in the Barony of West Carbery.

The pedigree of this clan above referred to is amongst the Carew Collection of MSS. at Lambeth Palace. It appears to have been very carefully compiled, and reaches from 1180 to the early part of the 17 th century. ${ }^{1}$ From this pedigree we see that Teige Roe's two sons, Finin and Shane (John) were the founders of two branches designated respectively the "Sliochd Finin"' and "Sliochd Shane." After some centuries, the last male representative of the Sliochd Finin, of which anything is known, was a Teige, son of Donogh. This Teige was fifth in descent from Finin, the founder of the branch and had three daughters but no son, so that the branch had become extinct in the male line. Now, the fifth in descent from the other brother, Shane, was Teige-na-Mucklagh, who is marked in the pedigree as living in 1602, and then aged 97. He seems to have been the founder of a new branch called the Sliochd Na Muccalagh or Mucklagh. ${ }^{2}$ Now, a natural son

1 A copy of it is given with this article. There is another old pedigree of the clan in the Royal Irish Academy, which differs somewhat from it, but not in material points. Moreover O'Hart places Tadhg Ruadh as one of the brothers of Cormac Liathanach instead of his descendant.

2 Muclach, in Irish, means a herd of swine; and is the name of several townlands in Ireland. Mucfhalach (which is pronounced somewhat similarly, and is the form given in some Irish pedigrees), means a place where swine are fed. It is not clear how the name came to be applied to this particular branch of the MacCarthys. Perhaps some ancestor may have owned extensive herds of swine. In the Down Survey map there is marked, at the head of Dunmanus Bay and opposite Coolnalong, a small island called "Muckly" Islaind. 
of his, named Dermond, married More, one of the three daughters of Teige, the last male representative of the Sliochd Finin. It is also to be noted that this Teige sold his lands to an Englishman called William Kerbye (?), and that the latter afterwards resold them to Dare, one of the legitimate sons of Teige-na-Mucklagh. The effect of this latter sale must have been to bring the great bulk of the Sept lands into the possession of the Mucklagh branch. Teige-na-Mucklagh is the person referred to in the Carew Papers, where we read that "Tege McCartan alias Tege McMockle signed articles between the freeholders and commissioners of Carbery on the 15 December, 1592."'

At page 424 of the second vol. of the "Pacata Hibernia" is given a "List of the names of such of the Irish as have shipped themselves for Spain." Amongst those who embarked at Kinsale in December, 1601, we find the names of Teig Oge ne Mockloghe and Owen Mac Teig ne Mockloghe. In the accompanying pedigree we find two sons so named of Teige-na-Mucklagh, who are, no doubt, the very same persons.

Amongst the MSS. preserved in the library of Trinity College, Dublin, is the following scrap of pedigree :-

\section{MacCARTHY}

T'eig MeCarthy of Ballinmoy, C.C., gt.

Danyel of the same ob.; ib.; Mar. 1634, bur. in Bantry Ab.

$=$ Honora f. Corm. McCarty of K.coa gent.

Jo. f. and h. = Joan f. Fynin McOwen McCarty ; Teig = Ellen f. Lysah.

Katherine $=$ Teig. Gyles = Geo. f. O'Leary of Inchineaf. Corm. McCarty, Lysah O'Leary pd.

which will be more intelligible in the following tabular form :-

Teig McCarthy of Ballinmoy, Co. Cork, gent.

Daniel McCarthy d. March, 1634, buried in Bantry Church. $=$ Honora, d. of Cormac McCarthy of Kilcoe.

\begin{tabular}{|c|c|c|c|}
\hline $\begin{array}{l}\text { Tohn son and heir. } \\
=\text { Joanna dau. of } \\
\text { Finin McOwen } \\
\text { McCarthy. }\end{array}$ & $\begin{array}{l}\text { Teig } \\
\text { of Lisah O'Leary. }\end{array}$ & $\begin{array}{c}\text { Katherine } \\
=\text { Teig }\end{array}$ & $\begin{array}{c}\text { Gyles }=\text { George } \\
\text { son of } \overline{0} \text { 'Leary of } \\
\text { Inchinaneaf. }\end{array}$ \\
\hline
\end{tabular}


The particulars contained in the above pedigree are more fully given in the two following extracts from funeral entries which are given in the Journal of the Society for Preservation of the Memorials of the Dead :-

1. Daniel McTeige McCartie of Belamoyre in the County of Cork, gent., 4th son of 'Teige McCarty of the same, married Honora, dau. of Cormuck Mclartie of Kilcoe, in the same County, by whom he had two sons and two daughters, viz., John, son and heir, married to Joan, dau. of Fynin McCarty, of Gortnaclohy, in the said County. Teige, 2nd son, married Ellen dau. of Lisagh O'Leary, of Inchinineafa (no doubt Inchineneave in the parish of Kilbarry, nchigeela). Katherine, married Teige McCormuck McCarty of Scartie in the said County, which Cormuck and Catherine died leaving issue one daughter. Giles, 2nd daughter, married to George O'Leary, son of Lysah O'Leary aforesaid. The saia Daniel died at Balemore aforesaid the ...... March, 1634 , and was interred in the Abbey of Bantry.

2. Teige McCormuck McCarty of Scarty, in Co. Cork, son and heir of the said Cormuck, died at Capueboy (district of Douce, Kealkill, Bantry), Co. Cork, Nov. 1634, and was interred in the Abbey of Inischorcan (Inisherkin) Co. Cork. The defunct married Katherine, daughter of Donel McCarty of Ballamoye, who had issue one daughter.

It will be seen that these extracts give a few further particulars regarding those parties.

In the first of them Finin McCarthy, whose daughter married John, elder son of Daniel MacTeig McCarthy, is mentioned as "of Gortnacloghy." Teig, the younger son, married Lysah O'Leary of Inchineaf. Katherine married Teig McCormac Carthy of Scarty. Moreover, in the second Daniel McTeige McCarthy's residence is given as Belamoyre and Balemore instead of Ballinmoy.

Now, referring to the Lambeth Palace pedigree, we find that Daniel, son of Teige-na-Mucklagh, married Honora, dau. of Cormac Mac Donal Cartie of the Sept of Clan Dermod, and owner of Kilcoe. So this Daniel, son of Teig-na-Mucklagh, and Daniel Mac Teige of Belamoyre must have been one and the same person, and Belamoyre must have been the residence of the Mucklagh branch. No place of this name can be traced on modern maps. But, in an old map of the year 1740, in the British Museum, there is marked a place called Belamire, not far to the west of Durrus. Now, the meaning of the word implies the existence in former times of a "ford." There was probably a ford of the "Four mile water" near the present village of Durrus, which, doubtless, is the modern name of the place formerly called Belamire. 
Now, let us try to identify Teige Mac Cormac of Scarty, who married Catherine, the daughter of Daniel Mac'Teigena-Mucklagh. It has been said that Dare, another son of Teige-na-Mucklagh, bought back from an Englishman the property sold to the latter by the last male member of the Sliochd Finin. That must have been the northern portion of the estate about Skart, just as the southern portion, about Belamire and Durrus, was that owned by Teige-na-Mucklagh. Now, who could have held this northern portion but a descendant of Dare Mac Teige-na-Mucklagh? From the pedigree we see that he had two sons, Cormac and Teig. The former of these was, in all probability, the father of Teige Mac Cormac.

In the Book of Distribution, Coolnalong and Baurgorm are entered as in the possession of John McCarthy als. Mucklagh. Other townlands in the parish of Durrus are entered as belonging to other McCarthys, doubtles of the same family. It will be seen, from the Trinity College scrap of pedigree, that Daniel Mac Teige of Belamoyre had two sons, John and Teig, as also appears from the Lambeth pedigree, and the elder of those was, in all probability, the John mentioned in the Book of Distribution.

In Smith's History of Cork we find the following:"Crossing the Bay of Dunmanus we come to another peninsula called Muinterbarry, washed on the east by Dunmanus Bay and on the west by Bantry Bay. Towards the north part the MacCarthys, who were known by the name of Mucklagh, had a good seat at a place called Coolnalong." In the Down Survey map we find the name applied to a piece of land at the north end of Dunmanus Bay, on its western shore, where it narrows to a point.

We find, from an Exchequer Bill of the year 1682, that one Daniel-na-Mucklagh McCarthy sued his brother-in-law, Owen Swiney of Mashanaglass, for the recovery of 40 head of cattle. There is very little doubt that this Daniel-naMucklagh belonged to the family of which we now write, though the Bill does not disclose his place of residence.

After that there is nothing on record about the family until comparatively recent times, and so there is a lacuna of some three or four generations in the line of descent be- 
tween, say, 1650 and 1750 , which we have so far been unable to fill up.

Towards the end of the 17 th century the ancestral estates seem to have passed away from the family; and during the greater part of the 18 th century many of them resided on the Continent, though not entirely out of touch with their kinsfolk in Ireland. About the end of it one of them, named Daniel McCarthy, who had been educated abroad for the priesthood, came back to Ireland, joined the Irish Mission, and, for some time before 1793, was Parish Priest of Durrus. But whilst holding that position he seems to have flung to the winds his vow of celibacy in contracting a marriage with a Miss Sarah Blair, residing in the same parish. The story goes that Captain Richard Blair of Blair's Cove, near Durrus, a Protestant, had married a Catholic lady. Their daughter, Sarah, was baptised and brought up in her father's faith. After his death his widow wished to have her converted to the Catholic religion, and, in order to bring this about, placed the matter in the Parish Priest's hands. But, as often happens, the "best laid schemes of mice and men gang aft a-gley;" and instead of the young lady being converted, as her mother desired, an attachment sprung up between her and her would-be spiritual director, which after a time led to their marriage. This appears from a marriage license bond of the Cork diocese, dated the 26th July, 1793, to have taken place in Cork about that time. There is nothing to show that the Rev. Daniel McCarthy ever changed his faith. On the contrary, there are strong reasons for believing that he lived and died a Catholic.

From the entry opposite his name in the Census returns of 1821, it would appear that he was born about 1761 . It is noted in this return that he was "formerly a Popish Priest." He died in December, 1828. Little is known about his life subsequently to his marriage, except that the Earl of Bantry, with whose family the Blairs were connected, got him some sinecure appointment with a fair income. ${ }^{3}$

3 It would appear that the Rev. Daniel was a remarkable person in many ways. He was educated abroad, and was a man of considerable 
The following is a pedigree of his descendants up to the present time:-

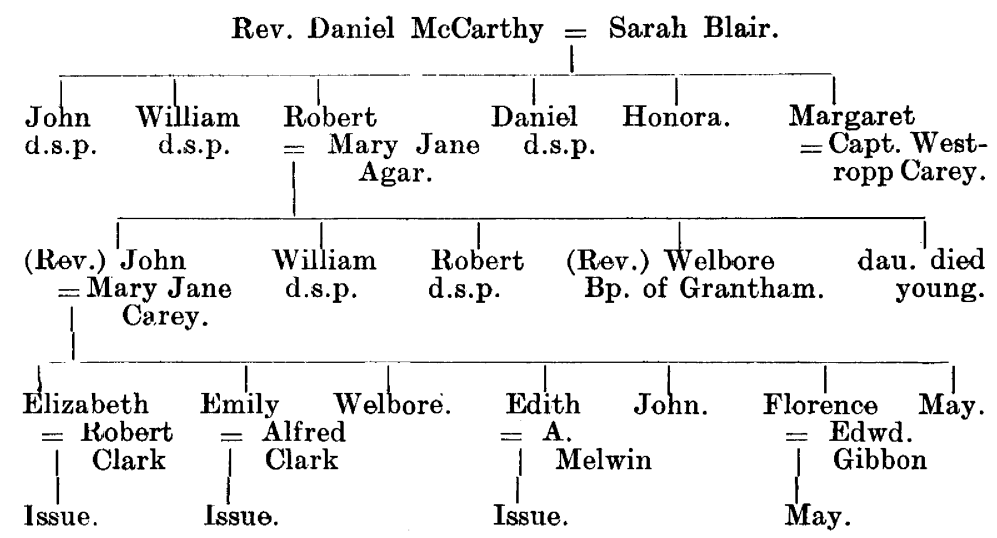

It will be seen that the family is now represented by the children of the late Rev. John McCarthy, and by his brother, the Right Rev. Welbore McCarthy, formerly of the Bengal Ecclesiastical Establishment, and now Bishop of Grantham, who is, in fact, the only male representative. He was for some time Archdeacon of Calcutta, and retired from the Indian Service in 1898. His elder brother John also spent some years in India, and was rector of a Norfolk parish after his return to England. He died about 25 years ago. One of his daughters, Florence, is the wife of Edward Gibbon, Esq., of Parr's Bank, Waterloo, near Liverpool, who has for some time devoted himself to researches into the history of this branch of the McCarthys, and to whom the writer of this sketch is indebted for all the information relating to the more recent period. It appears that the late Rev. John McCarthy, the elder grandson of the Rev. Daniel, though he never resided in Ireland, always styled himself "McCarthy of Durrus," and was very emphatic in his claim to belong

culture and a perfect French scholar. He was, 6ft. 4ins. in height and of distinguished presence. He is said to have been a severe disciplinarian, in regard to his four sons at least. He used to make them walk through the cemetery after dark and take them out in a boat in stormy weather so that they might develop the same courage which he himself possessed. They were all of unusual stature. The youngest, Daniel, was $6 \mathrm{ft}$. 7ins. tall, and by reason of his haughty mien was known as the "Oount." 
to the McCarthy Mor branch. He used to say that his greatgrandfather disputed with the then McCarthy of Carrignavar the right to the Chieftainship.

As regards this claim, it will be remembered that Cormac Liathanach, from whom the Clan Teige Roe descends, was the eldest son of Dermod, King of Cork (temp. Henry II.), and in his time the main line had not thrown off any of its numerous branches. Now, were it not for his disinheritance, his descendants would to-day constitute the senior branch of the Clann Carthaigh. Even that disinheritance does not take from the fact that, from a mere genealogical point of view, they may, in a way, be still considered the senior branch, though, no doubt, they are disqualified for the now barren honour of the Chieftainship and the title of "MacCarthy Mor." So that this claim, said to have been advanced by a member of the Clan Teige Roe a few generations back, cannot be considered altogether unfounded.

In looking through a volume of the "Dublin Penny Journal" for the year 1835 some time ago, we came across one of a series of articles entitled "Rides through the County Cork." The writer alludes to a ruined building which he visited at a place called "Four Mile Water," 4 on the northwest side of Dunmanus Bay, and of which an engraving is given in the Journal. ${ }^{5}$ We here quote what a friend who accompanied the writer, and who knew the locality, told him about it:-

"Antiquarian as I am, I know little of this ancient ruin save what Smith tells us in his 'History of Cork,' namely, that it was once a place of some strength, and was built by a branch of the MacCarthys. They lost that along with other possessions in the great Civil War, and their descendants struggled on for no inconsiderable part of a

4 "Four Mile Water" is so called because it is at the head of a stream of about that length running through the Clan Teige Roe valley and falling into the Bay of Dunmanus at the place now called Durrus. This latter name, however, has only been given to it in recent times, though the parish has always been so called.

5 Comparing with it a' photograph of the ruined house at Coolnalong taken by Mr. Gibbon, we can see that both are pictures of the same building, but there was more of it standing in 1835 , and there are slight dissimilarities which doubtless can be explained by the fact that the sketoh of 1835 was not taken with the same exactness of detail a's one would find in a modern photograph. 
century in the doubtful class entitled 'decayed gentry.' I well remember the last of them who lingered in this neighbourhood. He was an old patriarchal-looking man with snow-white hair. He inhabited a cottage near Dunbeacon. He was as finely formed and athletic a fellow as 1 ever saw. The peasants around regarded him with no small feelings of respect and affection, to which his excellent qualities appeared to entitle him well. He died at the age of 90 in the year-let me see-1795, I think, and he possessed to the very last the buoyancy of spirits and the warmth of affection that more properly belung to youth."

Some verses are also given which were made by this gentleman on the death of his aged friend, from which quote as follows:-

"I saw an old man laid within his shroud-

A placid smile sat on his lifeless tace

Which told the faith which cheered his dying hour,

And lingered still, like some lone golden beam

Cast on the silent heaven at eventide.

"His few thin hairs were snow-white, and his brow Still showed the wrinkles of life's carking caresCares that were ended and forgotten now!

While children and their children flocked around

'Their parent's bier, and sobs unbidden told

How well-beloved the soul that hence had fled!

The open heart the bounteous hand were all

Remembered at that sad and solemn hour."

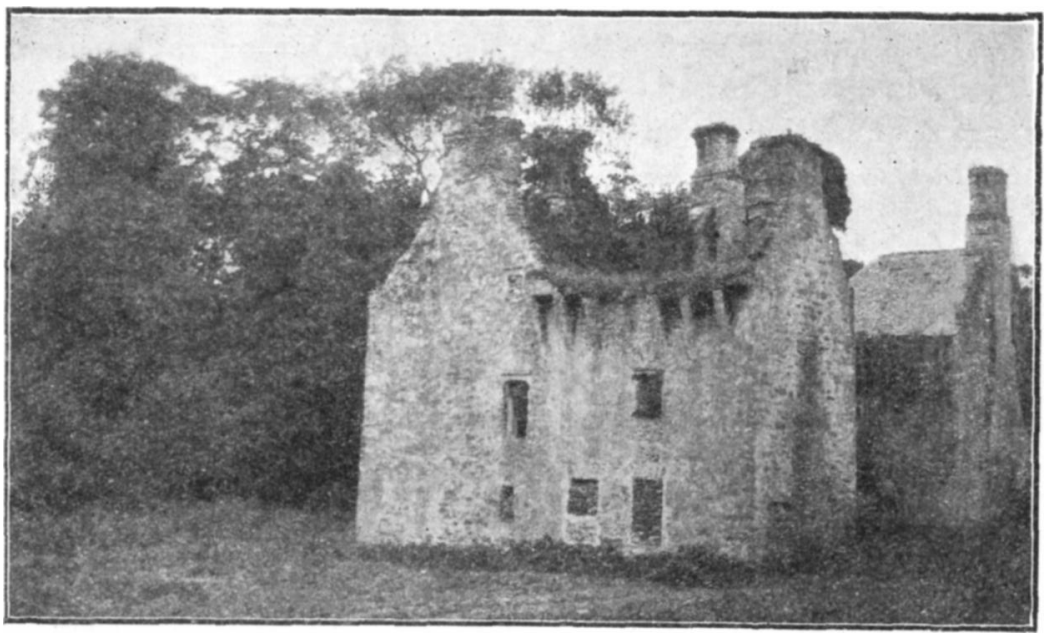

COOLNALONG. 
It seems highly probable that this old man was an ancestor of the Rev. Daniel McCarthy-possibly his grandfather.

As already mentioned, a pedigree of the Clan Teige Roe is appended to this article, for which we are indebted to $\mathrm{Mr}$. Alfred Clark, son-in-law of the late Rev. John McCarthy, who copied it from the Carew MSS.

\section{THE MACAR'TNEYS OF LISSANOURE.}

Donoch Cairtneach, the sixth son of Cormac Fionn MacCarthy Mor (b. 1170, d. 1242), who became King of Desmond, left two sons-

(1) Donal, of whom presently.

(2) Teige of Dun Mac Tomain, who had a dau., Sadhbh, who married 'Turlogh O'Brien, Prince of Thomond. Teige and his brother Donal, having made an attack upon the castle of Dun-Mac-Tomain, belonging to their first cousin, Dermod of Tralee, were seized by the latter, and by him held in captivity until released in 1311 by Donal Maol Lord of Carbery, their father's first cousin. Donal, the elder brother, afterwards joined Edward Bruce, when he invaded Ireland, and subsequently served under the standard of his brother Robert, King of Scotland, from whom he obtained a grant of lands in Argyllshire, whence some of his descendants removed into Galloway, and settled at Auchinleck in Kirkcudbright. A descendant of theirs, named George Macartney, a Captain of Horse, passed over to Ireland in 1649, and settled in the Co. Antrim, where he acquired a large estate. He served as High Sheriff of Antrim in 1678. By his first wife, a daughter of Sir Quintin Calderwood, he had a son, James, who was one of the Judges of the Court of Common Pleas in the reign of Queen Anne. By his second wife, Elizabeth Butler, he had a son, George, born 1671, who was M.P. for Belfast for 54 years, High Sheriff Co. Antrim, Deputy Governor, and Colonel of a regiment of Militia Dragoons. This George Macartney md. a dau. and co-heir of Sir Charles 
Porter, Lord Chancellor of Ireland, and died in 1757, leaving a son-

George Macartney, who md. Elizabeth, dau. of the Rev. John Winder, and had issue-

1. George Macartney, afterwards Lord Macartney, of whom we treat presently.

2. Elizabeth, md. John Blaquier, and died leaving an only daughter, Elizabeth.

Elizabeth Blaquier, niece of Earl Macartney md. in 1785 the Rev. Travers Hume, and died in 1805, leaving, beside four daughters, the following sons:-

1. George, who assumed the surname and arms of Macartney.

2. Gustavus, b. 1794, served in the R.A. at Waterloo.

3. John, b. 1795, md. 1st Anne Waller, dau. of John Parker, and, 2ndly, Elizabeth, dau. of Major Stewart, and had issue by both.

4. Robert (Rev.), md. 1823 Mary Harris, and had, with other issue, three sons, Gustavus, Robert, and John Richard, distinguished Army officers, who all received the Cross of the Legion of Honor.

The eldest son, George Macartney, J.P., D.L., and M.P. for Co. Antrim, b. 1793, md. Ellen, daughter and heir of Townley Patten Filgate, and had-

1. George Travers, his heir.

2. Townley Patten Hume Macartney Filgate.

1. Martha Ellen, md. Townley Filgate.

2. Elizabeth Jane.

3. Anne Sophia.

The elder son, George Travers Macartney, b. 1830, md. 1865 Henrietta Frances, dau. of Robert Smyth, and had with other issue-

Carthanach George Macartney, now of Lissanoure, born 1860, md. 1890 his cousin, Margaret Tryphena Mabel, eldest dau. of Townley Patten Hume Macartney Filgate, and has issue. 
George Macartney was born in May, 1737, at Lissanur in the county of Antrim. His father, George Macartney, was a country gentleman and landholder. His grandfather, also George Macartney, was M.P. for Belfast for 54 years. He also filled the office of High Sheriff, and was Deputy Governor of the county, and Colonel of a regiment of Militia Dragoons. The subject of our sketch graduated M.A. it Trinity College, Dublin, when he was 22, and was afterwards called to the Bar at the Middle Temple. Being unusually good looking and of prepossessing manners, he easily made and retained useful friendships. Thus it was that he became a chum of Stephen Fox, elder brother of Charles James Fox, and in this way got an introduction to his friend's father, Lord Holland. It was doubtless through the inHuence of the latter that he was, at the early age of 27, appointed Envoy Extraordinary to Russia. Before starting for St. Petersburg he was made a Knight Bachelor. He was charged with the duty of concluding a commercial treaty with the Russian Government, which, after long and diffcult negotiations, he accomplished to the satisfaction of both Courts. In the course of this business he showed so much tact and ability that he won the approval not only of Lord Holland and Fox, but also of the Empress Catherine, who conferred on him the Order of the White Eagle. Fox eulogised his address to the Empress on the occasion. "I think," said he, "your speech to the Czarina was one of the neatest things of the kind I ever saw, and I can assure you Burke admires it prodigiously."

At the age of 30 he was offered the high position of British Ambassador at St. Petersburg, but he declined the appointment, and soon afterwards entered Parliament as memioer for Cockermouth.

It was about this time that he married Lady Jane Stuart, daughter of the Earl of Bute. A year more passed, and he was made Chief Secretary for Ireland. He held the post fur three years, and then resigning, was made a Knight of the Bath. In 1775, at the age of 38 , he was made Captain General and Governor of Grenada, the Grenadines and Tobago, grouped collectively as the Caribbee Islands, and 
in the following year was raised to the Irish peerage as Baron Macartney of Lissanure. He was at Grenada in 1779 when the island was besieged by the French. After a gallant defence, he had to yield to superior force, and became a prisoner of war. As such he was carried to France, but he was soon exchanged. Returning to England, he re-entered Parliament, but had occupied his seat for only a few months when he was offered the Governorship of Fort St. George. As he was far from being in affluent circumstances, he was induced to accept the post.

He arrived in Madras in June, 1781, just as war had broken out between England and Holland, and he lost no time in seizing Sadras, Pulicat, Negapatain, and other Dutch possessions.

Lord Macartney did not find his position at Madras a bed of roses, and he was unfortunate enough to come into hostile relations with more than one of his colleagues and fellowofficials. $\mathrm{H}_{e}$ was, of course, of superior social rank to the generality of the Company's servants in India during his time, and besides he soon came to be regarded as an interloper, who would neither stoop to irregular practices himself, nor tolerate them in his subordinates. Shortly after his arrival he caused much sensation by refusing a gift of money, equivalent to some $£ 30,000$, offered by the Nabob of the Carnatic, who had invited him to his palace for the purpose of making the presentation. To all his host's protestations that it were merely a complimentary present, customarily made to every new Governor, and never before refused, Macartney turned a deaf ear, and remained firm in his refusal. And it may here be remarked that, during the whole of his sojourn in Madras, he fully sustained this high standard of official integrity.

He did not "hit it off"' very well with Warren Hastings, the Governor General, who doubtless was not pleased with the independent attitude assumed by his southern confrère. Lord Macartney having already filled high positions, and being an official of varied experiences, was naturally not willing to submit to Warren Hastings, whose experience was comparatively limited. It is probable, too, that Hastings 


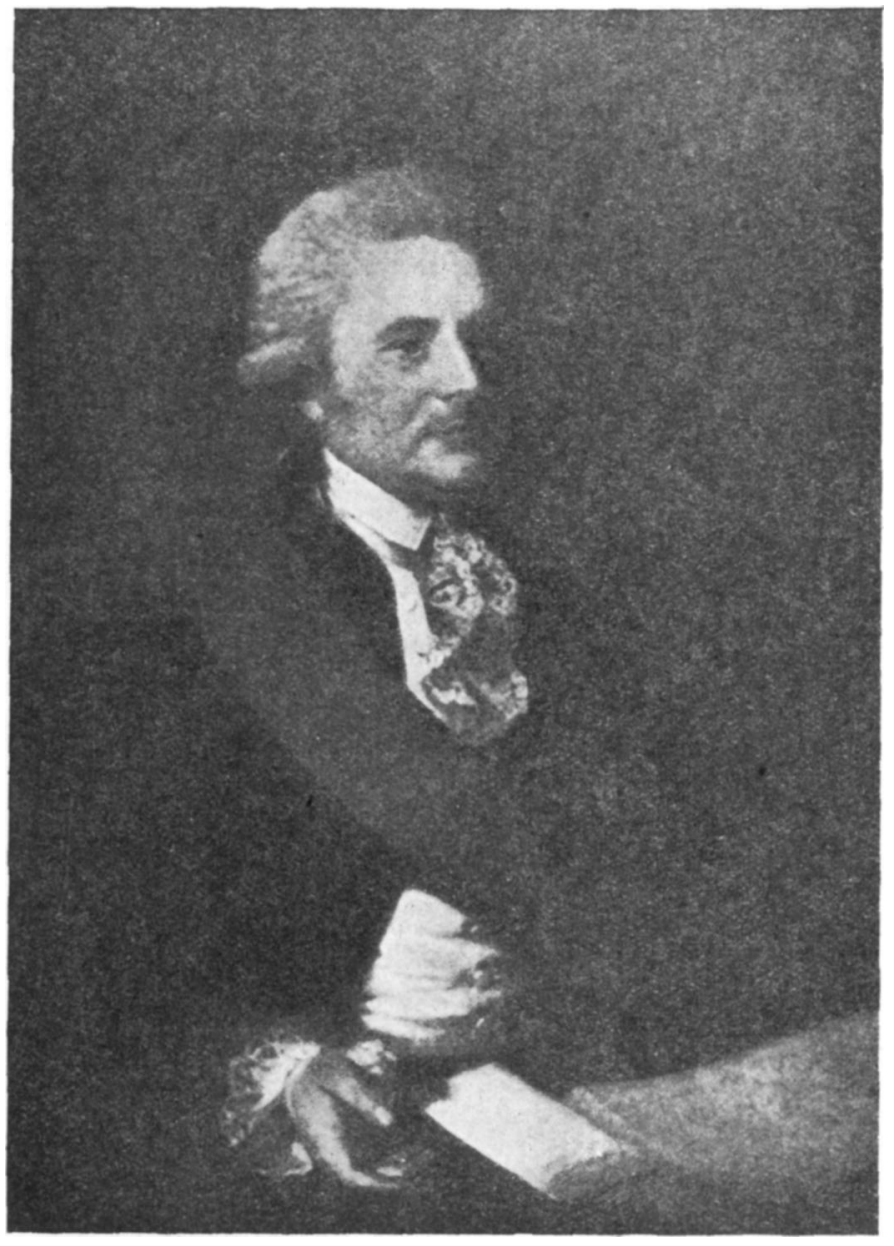

EARL MACARTNEY, K.B. All use subject to http://about.jstor.org/terms 
regarded with some jealousy the handsome Governor of Madras, who had such powerful friends at his back. Macartney worked harmoniously with Sir Eyre Coote, the Commander-in-Chief in India, who was occupied with the war against Hyder Ali and the Mahrattas, and got on very well with him for a time. But after a while differences of opinion arose. For one thing, the General was forced, by the exigencies of a costly war, to make heavier demands on the Treasury of Fort St. George than the Government could meet. Moreover, he resented Lord Macartney's policy of subordinating the military to the civil power, and the interference of the Government with his conduct of the campaign. Lord Macartney, with all courtesy, contended that while Sir Eyre remained in the Madras Presidency his proceedings should be governed by the resolutions adopted by the majority of the Madras Council. On this point he held his own, and not only did he, during his tenure of office, consistently subordinate the military to the civil authority, but after his return home pressed it as an essential on the Board of Directors. Sir Eyre Coote took advantage of a pause in the war to proceed to Calcutta to recruit his health. But sufficient time there had not elapsed for its complete restoration, when the Governor General and Council, in consequence of Tippu Sahib's action (who after the death of his father, Hyder Ali, had renewed hostilities with increased energy) ordered Sir Eyre back to Madras to resume the command of the local forces. But, being still in poor health, he died two days after reaching Madras.

When Sir Eyre Coote had to leave Madras on account of illness, the local command-in-chief devolved on Sir John Stuart. But he and Lord Macartney never worked in harmony. Sir John took offence because the Governor did not allow him the same free hand as was allowed to Sir Eyre Coote. The reason was that Lord Macartney considered that Stuart showed little military resource, and he had a poor opinion of his capacity. Sir John showed great unwillingness to carry out the Government plan of campaign, first with Tippu Sultan, and later against the French at Pondicherry. In fact, it was not until he had been actually super- 
seded that he proceeded to carry out the orders of Government, and open negotiations with the Marquis of Bussy.

After General Stuart's return to Madras, he adopted such an insulting attitude towards the Governor personally and the Select Committee collectively, that Lord Macartney was compelled to recommend to the Select Committee Stuart's dismissal, on the ground not only of his insubordination, but also of his incapacity. The Select Committee adopted this proposition. Nevertheless the General denied the authority of the Government to dismiss him, and asserted that such authority rested with the King only. The end of it was that Lord Macartney had to send a troop of Sepoys to the General's rseidence to seize him. He was then kept under arrest until a passage to England was secured for him in a ship which sailed shortly afterwards.

Sir John, as may be observed, was a very headstrong and obstinate man. It may be added that he had some years previously taken a prominent part in the proceedings which led to the deposition of Lord Pigott, a former Governor of Madras. For this reason, doubtless, Lord Macartney all the more realised the necessity of adopting strong measures against him.

On the suspension of General Stuart, the Government intimated to Sir John Burgoyne (in command of H.M.'s 23rd Dragoons, which he had then recently brought from England) that he, as the senior officer (though then only 35) was to officiate as Commander-in-Chief. He proceeded to act on this intimation, but, at the instance of General Stuart, who informed him that he (Stuart) insisted on retaining the command, he begged to decline assuming it until that General had relinquished it. Consequently, when Stuart was put on board ship soon afterwards, the Government resolved to pass over Sir John Burgoyne, and conferred the command on Colonel Lang. This decision irritated Burgoyne so much that he maintained, from that time out, a very insubordinate and insulting attitude towards the Governor. But, for all his irregular conduct, he seems to have been let down lightly by Lord Macartney, who was by nature a very 
kindly and forbearing man. ${ }^{1}$ He probably made allowances for Burgoyne's comparative youth. Burgoyne died in Madras on the 23rd September, 1785, three days after completing his 39 th year.

It has already been intimated that, between the Governor General and Lord Macartney, there was not much cordiality of feeling. After the death of Hyder Ali, who had usurped the government of Mysore, and waged war against the English, Lord Macartney, considering that the time was opportune for taking energetic measures against 'Tippu, and thinking it desirable to march an army into Mysore, made a recommendation to that effect. But Warren Hastings failed to realise the urgency of this measure, and a considerable time elapsed before any action was taken. Lord Macartney had with much difficulty obtained from the Nabob of the Carnatic an assignment of the revenues of the Carnatic for the conduct of the war. This was disapproved by the Government of Bengal, and the assignment was ordered to be rescinded. Then the treaty concluded by Macartney with Tippu Sahib was also disapproved, among other reasons, because it did not include the Nabob of the Carnatic, and a new ratification declaring it to extend to that personage was directed to take its place. This, of course, was opposed by Macartney. But now the ill state of his health, broken down by the fatigue and vexations he had undergone, led him in June, 1785, to resign his post. But before leaving India he proceeded to Calcutta, in the hope of bringing the provisional Governor General-for Hastings had just left for England-and his Council round to his way of thinking about affairs in Mysore and the Carnatic. While thus fruitlessly engaged he fell seriously ill. Just then came from the Court of Directors an offer of the Governor Generalship. But he declined the honour, and as soon as he was well enough started for England. Besides the break down of his health,

\footnotetext{
1 In illustration of his forbearance we may quote the following remarks from a letter he wrote on one occasion in reference to another official, who had given him some trouble:-“I never retort any sharp expression which may occur in his letters. In fact, I court him like a mistress, and humour him like a child; but, with all this, I have a most sincere regard for him, and honour him highly."
} 
it is known that he had other reasons, too, for leaving India, particularly the necessity which he felt for submitting to his Majesty's Ministers certain regulations which he considered indispensable for the salvation of India, and also the conditions on which he would be able to take up and fulfil the duties of Governor General with advantage to the public and reputation to himself.

We cannot conclude this sketch of Lord Macartney's career in Madras without recounting a curious incident which might have had for him a fatal issue, that is to say, an affair of honour, to which he was a party. Amongst the officials then in the service was a Mr. Hudlestone, who held the post of Military Secretary to Government. Lord Macartney, who had seen a good deal of him, was so pleased with his services that he wished to mark his appreciation of them by an increase of salary. He broached the matter to his colleagues, and they one and all approved of his suggestion. But when he brought the subject up again, in view to confirmation, Mr. James Sadlier, the third member of Council, objected to it. His colleagues reminded him that when the topic was first introduced he had given his concurrence. But he denied having ever expressed approval, and he did so in such an offensive manner that the Governor lost his temper and declared that he lied!

It is needless to say that this unparliamentary expression was no sooner used than regretted by Lord Macartney, who there and then apologised for it to the Committee. But Mr. Sadlier's military friends told him that he owed it to himself as a man of honour to demand satisfaction. He therefore sent a challenge to the Governor through his friend, Major Grattan. Lord Macartney complied, and referred his visitor to Mr. Davidson, the First Member of Council, who would act on his behalf. On the following morning the parties fought with pistols, the result being that Lord Macartney was slightly wounded, whilst Sadlier escaped unhurt.

On the 1st June, 1785, a few days before sailing for England, Lord Macartney signed a declaration in regard to his pecuniary circumstances, from which it appears that he was then returning to England richer by some $£ 30,000$ 
than when he landed in India. "When the whole of this sum," he wrote to the Court of Directors, "is applied to the arrangement of my private affairs, I shall possess a very small, if any, addition to my family inheritance."

He arrived in London on the 9th Ferbuary, 1786. Four days afterwards he met the Chairman and Deputy Chairman of the East India Company at the India House, and laid before them his views about the necessity of subordinating the military to the civil authority in India, and regarding other administrative matters, intimating that in case his views were accepted and certain abuses removed, he would still be willing to accept the appointment of Governor General. Lord Macartney's views having been communicated to the Ministers of the King, he was invited to an interview with Mr. Pitt and Mr. Dundas. No important differences existed on the points previously discussed at the India House; but when Lord Macartney urged the necessity, for his own reputation and the benefit of the public service, of his receiving, before his departure for India, some distinguished mark of the Royal favour, Mr. Pitt (notwithstanding the fact that he, as well as Mr. Fox, had eulogised him for his administration in Madras) at once showed that he deemed it inexpedient to advise the King to bestow on him a British peerage. Three days afterwards the Governor Generalship was offered to and accepted by Earl Cornwallis.

The Board of Directors unanimously voted to Lord Macartney an annuity of $£ 1,500$ "in recognition of the unexampled integrity" which, in their judgment, he had displayed as Governor of Fort St. George. As he lived to enjoy this annuity for 20 years, he received in all $£ 30,000$, curiously enough the equivalent of the sum which he had declined to accept from the Nabob of the Carnatic!

On the day following Lord Macartney's arrival in England he received a communication from General Stuart, late Commander-in-Chief of Madras, who since his compulsory retirement, some two years previously, had been nursing his wrath against him. This was a copy of a petition to the King, wherein he stigmatised as false Lord Macartney's imputations against him. During the following three days 
some correspondence passed, concluding with a note from the General announcing his intention of sending a friend to arrange for a hostile meeting. But Lord Macartney heard nothing more until the 27th May, or more than four months afterwards, when he received a letter, through Colonel Gordon, from the General, demanding satisfaction. The result of this was that a meeting was arranged near Kensingtin for the 8th June, at half-past four in the morning. Accordingly the ex-Governor and ex-Commander-in-Chief met at the place appointed, Colonel Fullerton acting as Lord Macartney's second. As the General had had one leg shot off by a cannon ball during a fight with Hyder Ali, he was placed with his back against a tree. The combatants fired simultaneously. The General's bullet lodged in Lord Macartney's right shoulder, whereupon the seconds intervened, and declared that honour was now satisfied. The General at first demurred, declaring that he had had no satisfaction, and that he wished to continue the duel, but the seconds were firm, and would not allow it. So the parties soon afterwards left the ground with their seconds and two surgeons who were in attendance.

Lord Macartney soon recovered from his wound. He indulged for a time in a spell of well-earned rest; and with his graceful person, suave manners, and winning address, soon regained his former popularity as a member of society. But eventually in 1792, when the Government, in consequence of the exactions and acts of injustice perpetrated by Chinese on English subjects, resolved to despatch an embassy to Pekin, Lord Macartney was selected as plenipotentiary, being the first English envoy sent to China. On his arrival he was well received, and managed to evade the necessity of doing homage to the Emperor in Chinese fashion. For two years, in the course of which he collected much information, he rendered important service, though he failed to obtain permission to have a British Minister resident in China. Immediately before his return to England, in 1794, the title of Baron, conferred on him in 1776, was changed into that of Earl Macartney in the peerage of Ireland, and Baron Macartney of Parkhurst in the Peerage of England. 
In 1795 he was sent to Italy on a confidential mission to Louis XVIII., then an exile at Verona, with orders to reside near the King. He remained at Verona until Louis removed to Germany the following year. After that he held the Governorship of the Cape of Good Hope, where he made a good impression on the Boers, from 1796 until 1798, when he was compelled by declining health to resign. On his return from the Cape, he took a house in Curzon Street, Mayfair, as well as a long lease of Coney House, Chiswick. He died at Chiswick in March, 1806, from his old enemy, gout, leaving no issue. Lady Macartney, to whom he bequeathed his property for her life, died at Coney House in 1828, aged 86, whereupon his property devolved upon Mrs. Hume, his niece and adopted daughter. From her it has descended to her great grandson, Mr. Carthanach George Macartney of Lisannoor, the present holder of it.

Lord Macartney wrote a "Sketch of the Political History of Ireland" and a "Journal of the Embassy to China." An account of his public life, with a selection from his unpublished writings, was published by his private secretary, Barrow, in two volumes, London, 1807. Sir George Staunton, who accompanied him to China as secretary, wrote an account of his Chinese Embassy in two volumes, London, 1797.

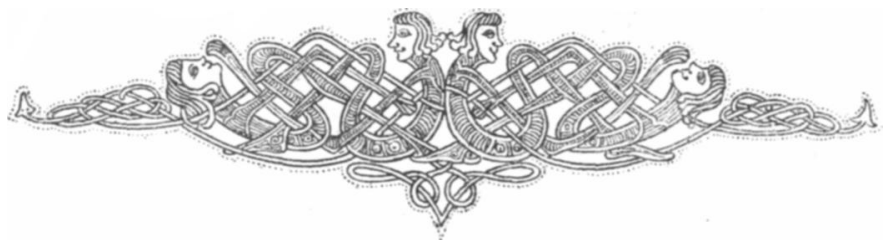

